\title{
Evaluation of apical leakage in root canals filled with different sealers
}

Avaliação do desempenho de diferentes cimentos obturadores no selamento apical de canais radiculares
Simone Helena Gonçalves de OLIVEIRA

DDS,MsC,PhD - Department of Bioscience and Diagnosis - School of Dentistry of São José dos Campos - UNESP - Sao Paulo State University - São José dos Campos - São Paulo - Brazil.

Gleyce Oliveira SILVA Flávia Goulart da Rosa CARDOSO MsC, PhD Student - Department of Restorative Dentistry and Endodontics - School of Dentistry of São José dos Campos - UNESP - Sao Paulo State University - São José dos Campos - São Paulo Brazil.

Rafaela Andrade de VASCONCELOS DDS - Department of Restorative Dentistry - School of Dentistry of São José dos Campos - UNESP - Sao Paulo State University - São José dos Campos - São Paulo - Brazil.

Ana Claudia Carvalho XAVIER MsC, PhD Student - Department of Restorative Dentistry and Endodontics - School of Dentistry of São José dos Campos - UNESP - Sao Paulo State University - São José dos Campos - São Paulo Brazil.

\section{Abstract}

Objective: To evaluate the apical leakage exhibited by root canals filled with gutta-percha points and three different endodontic sealers. Material and Methods: Thirty-five human molars were used and had their palatal (maxillary molars) and distal roots (mandibular molars) sectioned, standardized and instrumented with Mtwo rotary system. The roots were filled through active lateral condensation technique and divided into three groups $(\mathrm{n}=10)$, according to the endodontic sealer employed: G1- AH Plus, G2- Fill Canal, G3- MTA Fillapex. All groups were filled by gutta-percha points and endodontic sealer. Gutta-percha points were immersed into sodium hypochlorite for $24 \mathrm{~h}$ to achieve disinfection. After the filling procedure, the roots were immersed into Indian ink for posterior diaphanization and obtainment of the images through stereomicroscopy. By analyzing the images in Adobe Illustrator CS5 software, the level of apical leakage was determined. The data obtained were submitted to Kruskal Wallis and Dunn tests, with level of significance set at $5 \%$. Results: Statistically significant differences were found between G1 and G3. G2 did not show statistically significant differences. G1 exhibited the smallest apical leakage mean (12.85), followed by G2 (109.84) and G3 (101.15). Conclusions: Root canal obturation with gutta-percha points and AH plus sealer through lateral condensation technique provided lower apical leakage rates than the other endodontic sealers evaluated.

\section{KeYWORDS}

Sealers; Sodium hypochlorite; apical leakage.

\section{Resumo}

Objetivo: Avaliar a infiltração apical apresentada em canais radiculares obturados com guta-percha e três diferentes cimentos obturadores. Material e Métodos: Foram utilizados 35 molares humanos, os quais tiveram suas raízes linguais (molares superiores) e distais (molares inferiores) seccionadas, padronizadas e instrumentadas com o sistema rotatório Mtwo. As raízes foram obturadas através da técnica de condensação lateral ativa e divididas em 3 grupos $(n=10)$, de acordo com o cimento obturador utilizado: G1- AH Plus, G2- Fill Canal, G3- MTA Fillapex. Todos os grupos foram obturados com o conjunto guta-percha e cimento obturador, sendo que a guta-percha utilizada permaneceu $24 \mathrm{~h}$ imersa em hipoclorito de sódio, para sua desinfecção. Após a obturação, as raízes foram imersas em corante tinta da Índia, para posterior diafanização e obtenção de imagens através de estereomicroscópio. Através da análise das imagens no programa Adobe Illustrator CS5 foi determinado o nível de infiltração apical. Os dados obtidos foram submetidos aos testes estatísticos de Kruskal Wallis e Dunn, com nível de significância 5\%. Resultados: Verificou-se presença de diferença estatística significante entre o G1 e G3, sendo que G2 não diferiu estatisticamente dos demais grupos. O G1 apresentou a menor média de infiltração apical (12.85), seguida pelo G2 (109.84) e G3 (101.15). Conclusões: A obturação de canais radiculares com cones de guta-percha e cimento AH plus através da técnica de condensação lateral proporciona baixos índices de infiltração apical, quando comparada aos demais cimentos obturadores avaliados.

Cimentos obturadores; Hipoclorito de Sódio; Infiltração apical.

\section{Palavras-chave}




\section{INTRODUCTION}

The presence of microorganisms and toxins within the root canal system plays an important role in the etiology of the pulpal and periapical diseases. Therefore, the elimination of these agents through chemical and mechanical procedures is of extreme importance for endodontic treatment success [1-3]. Thus, it is mandatory the maintenance of rigorous asepsis and antisepsis patterns during all endodontic treatment to establish an aseptic chain at the beginning of the treatment which must be kept until the root obturation and tooth restoration.

Aiming to stimulate the repair process of the periapical tissues and promote the waterproofing after its cleaning and disinfection, the root canal must be filled with materials displaying adequate physical-chemical properties and biocompatibility [4].

Over the last 100 years, the materials most employed in root canal obturation are guttapercha points and endodontic sealer [5]. The most common obturation technique employed is lateral condensation, which represents the gold standard in Endodontics [6].

After the use of these aforementioned materials and techniques, gutta-percha points are in close contact with the periapical tissues, which therefore must be disinfected prior to its use. Because of its thermoplastic features, gutta-percha points cannot be submitted to the physical methods of sterilization, where either moist or dry heat is used resulting in the alteration of its structure $[2,3]$. Accordingly, chemical agents should be employed for its decontamination. For this purpose, there is a large option of chemical products, among which can be cited: chlorhexidine and sodium hypochlorite, mainly because their antimicrobial properties $[7,8]$. Because it is the most common irrigant used, sodium hypochlorite was the solution chosen for this study.

Although this irrigant promotes a fast and adequate disinfection, a study shows that gutta-percha points immersed in $2.5 \%$ sodium hypochlorite for more than $24 \mathrm{~h}$ exhibited morphological alterations on their surfaces [3]. Notwithstanding, there are no reports on this influence on the adequate root canal sealing $[9,10]$.

Because in daily clinics, the gutta-percha may be immersed in sodium hypochlorite for a period higher than that required for its disinfection, it is of great importance to evaluate the sealing capacity of different sealers when they are used together with points presenting morphological alterations.

Currently, a great variety of endodontic sealers can be found and they are divided according to their chemical composition: resin (AH Plus and MTA Fillapex), zinc oxide and eugenol (Fill Canal), calcium hydroxide or ionomer cement [11]. Among them, AH Plus, Fill Canal and MTA Fillapex can be cited. AH Plus has been considered as the best existing resin cements. It is presented as two pastes and composed of a polymer of epoxy resin. This sealer exhibits radiopacity, biocompatibility, proper flowing and low solubility [12].

Zinc oxide and eugenol-based cement has been largely used, in Brazil, over the last decades because of its good physical-chemical properties [11,13]. Additionally to exhibit a proper flowing, radiopacity, adhesion to root canal walls and low solubility, this cement has also the advantage of demonstrating high antimicrobial activity against some microorganisms within root canals $[13,14]$. Notwithstanding, it shows high cytotoxic activity[15].

Recently introduced into dental market, MTA Fillapex is a MTA-based endodontic sealer. According to its manufacturer, it exhibits high radiopacity, low solubility, biocompatibility, excellent flowing and stimulation of bone deposition on the periapical area. Notwithstanding, this sealer displays low adhesion to root canal walls [16].

Based on the several options of filling materials, it is mandatory to evaluate the behavior of these cements when used together with gutta-percha points exhibiting morphological alterations. Therefore, the clinical practice of the dentists should be guided by scientific basis. Thus, the aim of this study was to evaluate the apical leakage of root canals filled with gutta-percha point excessively disinfected and three different endodontic sealers.

\section{Material And Methods}

This study was submitted and approved by the Ethical Committee in Research of the School of Dentistry of São José dos Campos - UNESP, under protocol n. 014/2008-PH/CEP.

Thirty-five human molars were extracted due to periodontal reasons. They had their palatal (maxillary molars) and distal roots (mandibular molars) sectioned with the aid of carborundum 
discs at low speed to standardize the lenght of the specimens at $11 \mathrm{~mm} \pm 1 \mathrm{~mm}$. Next, the roots were cross-sectioned at $1 \mathrm{~mm}$ short of the apical foramen to remove the possible presence of the apical delta.

The roots were instrumented with the aid of sizes 701 and 702 Mtwo rotary system kits (VDW, Munich, Germany) coupled to a rotary (VDW Silver, Romibras, Rio de Janeiro, Brazil). Root canals were irrigated with $3 \mathrm{ml}$ of $1 \%$ sodium hypochlorite $(\mathrm{NaOCl})$ (Asfer, São Caetano do Sul, São Paulo, Brazil) at every instrument change. Apical stop was standardized at size 35 gutta-percha point (Tanari, Manaus, Brazil) at $1 \mathrm{~mm}$ short of the apical area. At the ending of the instrumentation, the canals were embedded into EDTA solution (Biodinâmica, Ibiporã, Paraná, Brazil) for 3 min, which was removed by a new irrigation with 3 $\mathrm{ml}$ of $1 \% \mathrm{NaOCl}$. Then, the roots were externally sealed with two layers of nail polish (Risque Niasi, T. Serra, São Paulo, Brazil), except in the cervical and apical opening.

After the standardization of the specimens, they were divided into 3 groups, according to the sealer material employed: G1- filling with gutta-percha points and AH Plus sealer ( $\mathrm{n}=10), \mathrm{G} 2$ - filling with gutta-percha points and Fill Canal sealer $(\mathrm{n}=10)$, G3filling with gutta-percha points and MTA fillapex sealer $(n=10)$.

Prior to the filling process the gutta-percha points were disinfected through immersion into $1 \%$ sodium hypochlorite for $24 \mathrm{~h}$.

The obturation of all specimens was performed through active lateral condensation technique. In this technique, the main gutta-percha point was involved in endodontic sealer and introduced into the root canal up to the working lenght. Following, secondary points were added with the aid of a digital spacer (Dentsply Ind. Com, LTDA, Petrópolis, Rio de Janeiro, Brazil), up to the complete filling of the root canals. Then, the excess was removed with heated carriers, and the specimens were radiographed at mesial-distal and buccal-lingual directions to verify the adequate filling of the root canal with the material.

Next, all specimens received a thick layer of sticky wax (Asfer Indústria Química Ltda, São Caetano do Sul, São Paulo, Brazil) to aid in the root external sealing. This layer was not applied onto the apical area, leaving the foramen visible. Then, the roots were immersed into Indian ink (Acrilex, São Bernardo do Campo, São Paulo, Brazil), taken to a vacuum environment of $20 \mathrm{mmHg}$ for $30 \mathrm{~min}$, and kept immersed into the ink in an incubator at 37 ${ }^{\circ} \mathrm{C}$ for more $24 \mathrm{~h}$. After this period, the roots were washed in running water for $24 \mathrm{~h}$ and the external sealing layers removed.

The specimens were then submitted to diaphanization process, through decalcification with $5 \%$ hydrochloric acid for 20 days under constant agitation. Then, the specimens were washed in running water for $3 \mathrm{~h}$ and dehydrated in increasing alcohol solutions $(80,96$ and $100 \%)$, for more $1 \mathrm{~h}$ at each one of the concentrations. To complete the diaphanization process, the specimens were clarified through immersion into methyl salicylate (Dinâmica, São Paulo, Brazil).

The specimens were then photographed through stereoscopy and the images analyzed by Adobe Ilustrator CS5 software (Adobe Systems Incorporated, São Paulo, Brazil), where the leakage levels were measured. The data obtained were submitted to statistical analysis by Kruskal Wallis and Dunn tests with level of significance set at $5 \%$.

\section{Results}

The data obtained were submitted to descriptive statistics (Table 1). After Kruskal-Walis test, it was verified statistically significant differences among groups $(\mathrm{Kw}=7.7080 ; \mathrm{df}=2 ; \mathrm{p}$-value $=0.0212<0.05)$. There were statistically differences between G1 and G3 according to Dunn test (5\%); group 2 did not show statistically significant difference regarding to other groups (Table 2). Thus, the lowest leakage was verified in G1 (AH Plus), with leakage mean of $12.85 \mathrm{~mm}$. The other groups exhibited high levels of apical leakage, with means of: 109.84 (G2) and 101.15 (G3). These leakage values can be seen in Figure 1, which displays in millimeters the Indian ink leakage in the three different groups.

Figures 2A-B and 3 shows the apical leakage in each one of the groups evaluated.

\section{Table 1 - Descriptive statistics}

\begin{tabular}{c|c|c|c|c|c|c}
\hline Groups & $\mathrm{n}$ & Mean & SD & Minimum & Median & Maximum \\
\hline $\begin{array}{c}\text { MTA } \\
\text { Fillapex }\end{array}$ & 10 & 101.15 & 95.72 & 0.00 & 81.24 & 300.00 \\
\hline $\begin{array}{c}\text { Fill } \\
\text { Canal }\end{array}$ & 10 & 109.84 & 114.06 & 0.00 & 84.66 & 300.00 \\
\hline $\begin{array}{c}\text { AH } \\
\text { Plus }\end{array}$ & 10 & 12.85 & 15.05 & 0.00 & 10.61 & 50.10 \\
\hline
\end{tabular}




\section{TABLE 2 - Formation OF GROUPS With SIMILAR BEHAVIORS REGARDING TO LEAKAGE ACCORDING TO DUNN TEST $(5 \%)$, AFTER KRUSKal-Wallis TEST*}

\begin{tabular}{c|c|c|c}
\hline Groups & Median & Medium Poste & $\begin{array}{c}\text { Homogenous } \\
\text { Groups }^{* *}\end{array}$ \\
\hline MTA & 81.24 & 19.4 & $\mathrm{~A}$ \\
\hline FILL & 84.66 & 17.8 & $\mathrm{AB}$ \\
\hline AH & 10.61 & 9.3 & $\mathrm{~B}$ \\
\hline
\end{tabular}

MTA x FILL: difference $(19.4-17.8)=1.6<9.425 \mathrm{~ns}$

MTA X AH: difference $(19.4-9.3)=10.1>9.425 \mathrm{~s}$

FILL x AH: difference $(17.8-9.3)=8.5<9.425 \mathrm{~ns}$ level of significance (alpha) $=0.05$ critical value $Z=2.394$

critical value (difference) for comparison 9.4251

${ }^{*} \mathrm{kw}=7.7080 ; \mathrm{df}=2 ; \mathrm{p}$-value $=0.0212<0.05$

** established with the aid of Statistix 9.0 software

\section{Legends ANd Figures}

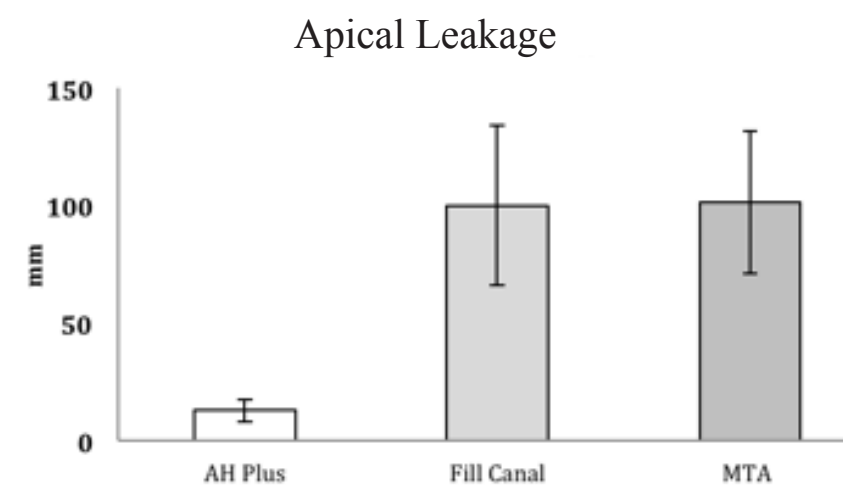

Figure 1 - Apical leakage $(\mathrm{mm})$ and standard error of $\mathrm{G} 1$, G2 and G3.

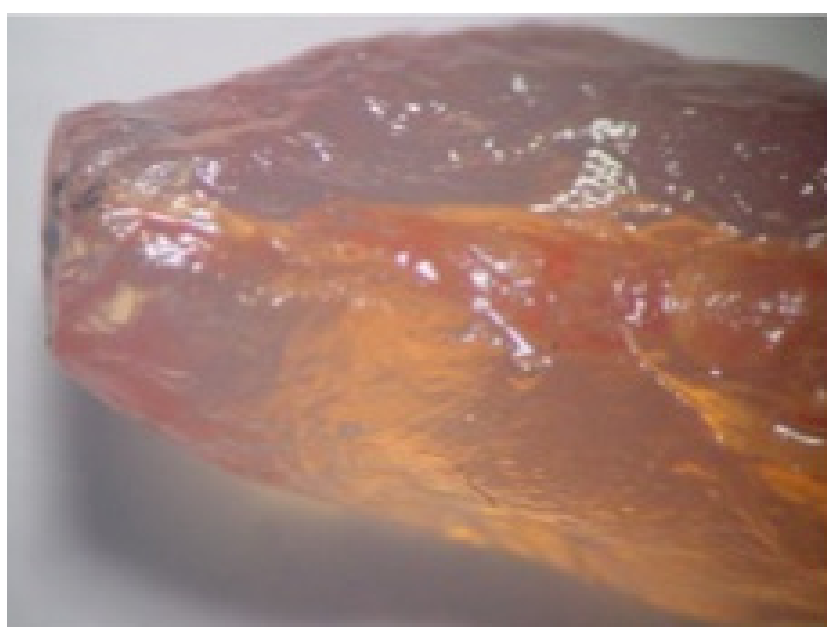

Figure 2 - a) Apical leakage observed in group G1 (AH Plus);

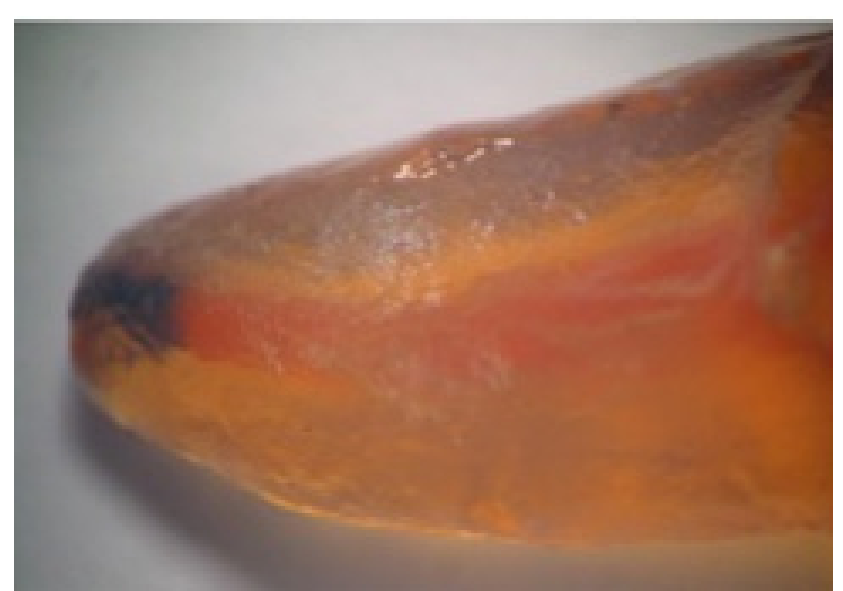

Figure 2 - b) Apical leakage observed in group G2 (Fill Canal).

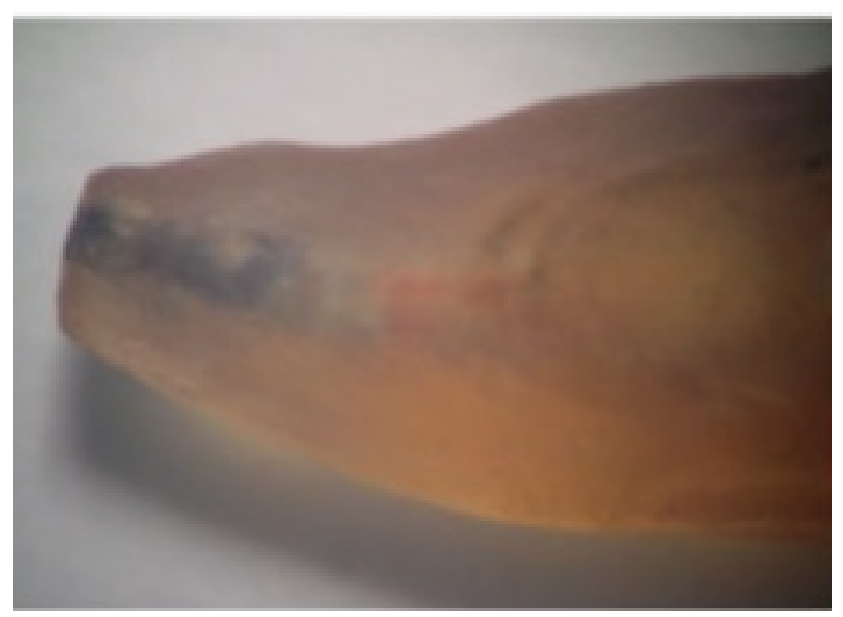

Figure 3 - Apical leakage observed in group G3 (Mta Fillapex).

\section{Discussion}

The endodontic obturation comprises the filling of the root canal by materials with adequate physicalchemical properties and biologically compatible, aiming to promote its sealing as much hermetic as possible, not interfering and, preferentially stimulating the repair process [4].

Additionally, the materials should be capable of undergoing sterilization to preserve the aseptic chain therefore not serving as vehicle for pathogenic microorganisms, once these materials may be in close contact with the periapical tissues. Because gutta-percha points are thermolabile they should be disinfected prior to its use by a chemical method [17]. However, the alterations during the sterilization of the points may cause the waterproofing of the endodontic obturation [18]. 
AH Plus, Fill Canal and MTA Fillapex sealers were employed in this study aiming to verify whether they were capable of filling the alterations caused by the chemical disinfection of the gutta-percha points, making apical leakage difficult. In this study, root canal filling was performed through lateral condensation technique, which is of easy execution and proved efficacy $[19,20]$.

The method of leakage analysis adopted was diaphanization because it enables to observe the root canal system through transparence. This resource has been used by several studies because it shows as advantages: the maintenance of the original root shape and the possibility of verifying small alterations existing in root canals as well as reducing the failure chances in which the teeth could be kept for longer time periods [21].

AH Plus was the endodontic sealer showing the smallest apical leakage mean (12.85) in teeth filled with gutta-percha points treated, exhibiting the best results when compared with the other groups. However, statistically differences were not found when compared with Fill Canal (109.84), while statistically differences were seen when compared with MTA Fillapex (101.15). Moreover, AH Plus exhibited the smallest standard deviation than the other sealers, indicating that despite of the fact that it provokes leakage, this does not deviate much from the teeth evaluated. It is worth emphasizing that all teeth employed had the same morphological type divided among groups. Fill Canal and MTA Fillapex, in addition to present high apical leakage, still obtained a very high standard deviation indication the highest instability of these materials.

AH Plus is a sealer commonly employed in daily practice, presented by the pastes developed from the chemical of epoxy resins, exhibiting easy handling, good adaptation to root canal walls, dimensional stability at long term [22,23] and satisfactory biocompatibility [24]. Although it shows better results than those of the other sealers analyzed, $\mathrm{AH}$ Plus was not capable of preventing apical leakage. These results are in agreement with those of ReissAraújo et al. (2009) [25], who observed that the sealers tested exhibited a similar behavior regarding to apical leakage through diaphanization. However, AH Plus sealer obtained the smallest level of leakage than Endofill, an oxide zinc and eugenol-based sealer. These findings are in agreement with those of De Almeida et al. (2000) [11], who verified that AH Plus sealer exhibited the best statistically significant results when compared with Fill Canal, an oxide zinc and eugenol-based sealer. Kopper et al. (2006) [26], verified that neither Endofill sealer nor AH Plus sealer were capable of preventing apical leakage.

MTA Fillapex is a new sealer based on MTA, also presenting a resin component in its composition. In this study, it showed the worst results, even than Fill Canal. As far as we are concerned, there are no studies on apical leakage of this sealer. If another MTA-based sealer (Endo-CPM-Sealer) is compared with AH Plus, the first exhibited the greatest dye penetration, although all samples showed apical leakage [27].

Despite the fact that other studies $[11,25,26]$ also verified the presence of apical leakage after the filling of endodontically treated teeth, the high leakage rate of MTA Fillapex and Fill Canal can be attributed to the excessive period of disinfection, once the decontamination of these gutta-percha points by different agents provoked the increase in the surface free energy, promoting a higher interaction between the gutta-percha point and the cements [28].

Among the sealers here studied, AH Plus showed the best results, exhibiting low apical leakage rate, and therefore it can be the sealer of choice for daily practice because it still presents the best physicalchemical properties when compared with the other sealers here evaluated.

It is still important to emphasize the need of further studies on the interaction between endodontic sealers and gutta-percha points disinfected, once apical leakage provoked by the lack of sealing can be the cause of endodontic treatment failure.

\section{Conclusion}

Root canal obturation with gutta-percha points and $\mathrm{AH}$ plus sealer through lateral condensation technique provides low apical leakage rates when compared with other sealers commercially available. 


\section{REFERENCES}

1. Dumani A, Yoldas O, Isci AS, Koksal F, Kayar B, Polat E. Disinfection of artificially contaminated Resilon cones with chlorhexidine and sodium hypochlorite at different time exposures. Oral Surg Oral Med Oral Pathol Oral Radiol Endod. 2007;103(3):e82-5.

2. Ozalp N, Okte Z, Ozcelik B. The rapid sterilization of guttapercha cones with sodium hypochlorite and glutaraldehyde. J Endod. 2006;32(12):1202-4.

3. Valois CR, Silva LP, Azevedo RB. Structural effects of sodium hypochlorite solutions on gutta-percha cones: atomic force microscopy study. J Endod. 2005;31(10):749-51.

4. Schwarze T, Leyhausen G, Geurtsen W. Long-term cytocompatibility of various endodontic sealers using a new root canal model. J Endod. 2002;28(11):749-53.

5. Mushtaq M, Farooq R, Ibrahim M, Khan FY. Dissolving efficacy of different organic solvents on gutta-percha and resilon root canal obturating materials at different immersion time intervals. Journal of conservative dentistry : JCD. 2012;15(2):141-5.

6. Kumar NS, Prabu PS, Prabu N, Rathinasamy S. Sealing ability of lateral condensation, thermoplasticized gutta-percha and flowable gutta-percha obturation techniques: A comparative in vitro study. Journal of pharmacy \& bioallied sciences. 2012;4(Suppl 2):S131-5.

7. Vianna ME, Gomes BP, Berber VB, Zaia AA, Ferraz CC, de Souza-Filho FJ. In vitro evaluation of the antimicrobial activity of chlorhexidine and sodium hypochlorite. Oral Surg Oral Med Oral Pathol Oral Radiol Endod. 2004;97(1):79-84.

8. Estrela C, Estrela CR, Barbin EL, Spano JC, Marchesan MA, Pecora JD. Mechanism of action of sodium hypochlorite. Braz Dent J. 2002;13(2):113-7.

9. Gomes BP, Vianna ME, Matsumoto CU, Rossi Vde P, Zaia AA, Ferraz CC, et al. Disinfection of gutta-percha cones with chlorhexidine and sodium hypochlorite. Oral Surg Oral Med Oral Pathol Oral Radiol Endod. 2005;100(4):512-7.

10. Nabeshima CK, Machado ME, Britto ML, Pallotta RC. Effectiveness of different chemical agents for disinfection of gutta-percha cones. Aust Endod J. 2011;37(3):118-21.

11. De Almeida WA, Leonardo MR, Tanomaru Filho M, Silva LA. Evaluation of apical sealing of three endodontic sealers. Int Endod J. 2000;33(1):25-7.

12. Reiss-AraúJo C, AraúJo SS, Baratto-Filho F, Reis LC, Fidel SR. Comparação da infiltração apical entre os cimentos obturadores AH Plus, Sealapex, Sealer 26 e Endofill por meio da diafanização. RSBO. 2009;6(1):8.

13. Cavalcanti AL, Limeira FI, Sales EA, Oliveira AA, Lima DM, Castro RD. In vitro antimicrobial activity of root canal sealers and calcium hydroxide paste. Contemporary clinical dentistry. 2010;1(3):164-7.

14. Sipert CR, Hussne RP, Nishiyama CK, Torres SA. In vitro antimicrobial activity of Fill Canal, Sealapex, Mineral Trioxide Aggregate, Portland cement and EndoRez. Int Endod J. 2005;38(8):539-43.

15. Leonardo RT, Consolaro A, Carlos IZ, Leonardo MR. Evaluation of cell culture cytotoxicity of five root canal sealers. J Endod. 2000;26(6):328-30.

16. Sagsen B, Ustun Y, Demirbuga S, Pala K. Push-out bond strength of two new calcium silicate-based endodontic sealers to root canal dentine. Int Endod J. 2011;44(12):1088-91.

17. Leonardo MR, Silva LA, Utrilla LS, Assed S, Ether SS.
Calcium hydroxide root canal sealers--histopathologic evaluation of apical and periapical repair after endodontic treatment. J Endod. 1997;23(7):428-32.

18. Estrela C, Ribeiro RG, Estrela CR, Pecora JD, Sousa-Neto MD. Antimicrobial effect of $2 \%$ sodium hypochlorite and $2 \%$ chlorhexidine tested by different methods. Braz Dent J. 2003;14(1):58-62.

19. Bonetti I, Filho MT, Leonardo R. Avaliação in vitro da capacidade seladora na região cervical de dentes obturados com Sealapex e Fill Canal. Influência do tempo de remoção parcial da obturação. Rev Odontol Unesp. 1997;26(1):87-107.

20. Valera M, Leonardo M, Filho IB. Cimentos endodônticos: selamento marginal apical imediato e após armazenamento de 6 meses. Odontol Univ São Paulo. 1998;12(4):355-60.

21. Pécora J, Savioli R, Vansan L, Silva R, Costa W. Novo método de diafanizar dentes. Rev Fac Odontol Ribeirão Preto. 1986;23(1):1-5.

22. Schafer E, Zandbiglari T. Solubility of root-canal sealers in water and artificial saliva. Int Endod J. 2003;36(10):660-9.

23. Versiani MA, Carvalho-Junior JR, Padilha MI, Lacey S, Pascon EA, Sousa-Neto MD. A comparative study of physicochemical properties of AH Plus and Epiphany root canal sealants. Int Endod J. 2006;39(6):464-71.

24. Bin CV, Valera MC, Camargo SE, Rabelo SB, Silva GO, Balducci I, et al. Cytotoxicity and genotoxicity of root canal sealers based on mineral trioxide aggregate. Journal of endodontics. 2012;38(4):495-500.

25. Reiss-Araújo C, Araújo S, Filho FB, Reis L, Fidel S. Comparison of apical leakage of endodontic sealers $\mathrm{AH}$ Plus, Sealapex, Sealer 26 and Endofill through clearing teeth. RSBO. 2009;6(1):21-8.

26. Kopper PM, Vanni JR, Della Bona A, de Figueiredo JA, Porto $\mathrm{S}$. In vivo evaluation of the sealing ability of two endodontic sealers in root canals exposed to the oral environment for 45 and 90 days. J Appl Oral Sci. 2006;14(1):43-8.

27. Costa C, Rocha V, Habitante S, DP DR, Marques J. Apical leakage analysis of a new MTA endodontic sealer. Cienc Odontol Bras. 2009;12(2):35-40.

28. Prado M, de Assis DF, Gomes BP, Simao RA. Effect of disinfectant solutions on the surface free energy and wettability of filling material. J Endod. 2011;37(7):980-2.

Received: 2012 Oct. 03 Accepted: 2012 Dec. 03

Corresponding author:

Simone Helena Gonçalves de Oliveira Avenida Francisco José Longo, 777 Jardim São Dimas - UNESP - Departamento de Biociências e Diagnóstico Bucal São José dos Campos - SP - Brasil CEP: 12254-000 email: simone@fosjc.unesp.br 